\title{
Analisis Deskriptif Pengguna Kosmetik Aktif di Surabaya
}

\author{
Navitasari Nabila, Gunawan Janti, dan Persada, S.F. \\ Departemen Manajemen Bisnis, Fakultas Bisnis dan Manajemen Teknologi, \\ Institut Teknologi Sepuluh Nopember (ITS) \\ e-mail: satriafadil@mb.its.ac.id
}

\begin{abstract}
Abstrak-Pertumbuhan Industri Kosmetik Indonesia bertumbuh secara positif setiap tahunnya. Tujuan dari penelitian ini adalah mengidentifikasi karakteristik demografis pengguna kosmetik merek asing. Penelitian ini menggunakan pendekatan deskriptif-konklusif dengan menggunakan pengumpulan data yang bersifat multi cross-sectional. Data penelitian ini diperoleh menggunakan survei kuesioner yang disebar di Surabaya dan menghasilkan 473 responden pengguna kosmetik aktif yang pernah menggunakan kosmetik merek asing. Hasil dari penelitian ini menunjukkan karakteristik demografi yang ada pada pengguna kosmetik aktif yang pernah menggunakan kosmetik asing.
\end{abstract}

Kata Kunci-Kosmetik, Merek Asing, Demografi.

\section{PENDAHULUAN}

$\mathrm{P}$ ASAR kosmetik global tahun 2017 diperkirakan mencapai nilai 4212 triliun rupiah atau 4,2 kuadriliun rupiah yang sebelumnya berada pada nilai 3,95 kuadriliun rupiah [1]. Nilai ini diperkirakan akan terus bertumbuh hingga nilai 5,8 kuadriliun rupiah pada tahun 2022 [2].

Wilayah Asia Pasifik memiliki kontribusi terbesar dalam pertumbuhan pasar kosmetik global. Indonesia merupakan wilayah paling berkembang dengan angka annual compound growth rate terbesar, yang kemudian disusul India di tempat kedua. Industri kosmetik Indonesia mencapai nilai 36 triliun p-iorupiah pada 2017 yang naik sebesar 12 persen dari tahun 2016 [2]. Serta business value pasar kosmetik Indonesia diperkirakan akan mencapai angka 100 triliun pada 2020 [3].

Industri kosmetik Indonesia terdiri atas produk asing dan produk lokal yang beredar di pasar kosmetik Indonesia. Namun dari banyaknya produk kosmetik yang beredar di Indonesia hanya 14.658 yang merupakan produk lokal dari keseluruhan 36.642 produk yang tersebar berdasarkan data BPOM. Selain itu, dari keseluruhan produk lokal yang beredar $70 \%$ bahan baku dari keseluruhan bahan baku didapatkan melalui impor [4].

Sehingga dirasakan kosmetik lokal perlu meningkatkan daya saingnya, dengan ketatnya persaingan dengan produk asing yang masuk ke pasaran dengan strategi yang tepat. Jenis kosmetik yang diteliti merupakan kosmetik yang diaplikasikan pada wajah. Berdasrkan bagian wajah, terdapat jenis kosmetik mata, kosmetik bibir dan kosmetik wajah [5].

Pembelian kosmetik tidak terlepas dari faktorfaktor yang mempengaruhi di dalamnya. Persepsi konsumen merupakan salah satu faktor yang memengaruhi keputusan pembelian konsumen. Merek memainkan peranan yang sangat penting dalam proses pengambilan keputusan konsumen. Sangat penting bagi perusahaan untuk mengetahui proses pengambilan keputusan konsumen dan mengidentifikasi kondisi dalam proses tersebut [6].
Tabel 1

Deskriptif Demografi Responden

\begin{tabular}{|c|c|c|}
\hline Profil & Frekuensi & Persentase $(\%)$ \\
\hline \multicolumn{3}{|l|}{ Usia } \\
\hline 17 - 20 Tahun & 134 & 28.32 \\
\hline 21 - 25 Tahun & 334 & 70.60 \\
\hline$>25$ Tahun & 5 & 1.06 \\
\hline \multicolumn{3}{|l|}{ Pendidikan } \\
\hline SMA/Sederajat & 300 & 63.41 \\
\hline Diploma & 41 & 8.67 \\
\hline Sarjana & 127 & 26.84 \\
\hline Pascasarjana (S2/S3) & 3 & 0.63 \\
\hline Lainnya & 2 & 0.42 \\
\hline \multicolumn{3}{|l|}{ Pekerjaan } \\
\hline Pelajar/Mahasiswa & 405 & 85.61 \\
\hline Wiraswasta & 8 & 1.69 \\
\hline Pegawai Swasta & 25 & 5.28 \\
\hline Pegawai BUMN & 4 & 0.85 \\
\hline Ibu Rumah Tangga & 3 & 0.63 \\
\hline PNS & 2 & 0.42 \\
\hline Lainnya & 26 & 5.50 \\
\hline \multicolumn{3}{|l|}{ Pemasukan } \\
\hline$<\operatorname{Rp} 2.000 .000$ & 342 & 72.29 \\
\hline $\begin{array}{r}\mathrm{Rp} 2.000 .000-\mathrm{Rp} \\
3.200 .000\end{array}$ & 77 & 16.28 \\
\hline Rp 3.300.000 - Rp & 37 & 7.82 \\
\hline $\begin{array}{r}5.000 .000 \\
R p 5.000 .000-R p\end{array}$ & & \\
\hline $\begin{array}{r}7.500 .000 \\
\end{array}$ & 10 & 2.11 \\
\hline$>\operatorname{Rp} 7.500 .000$ & 7 & 1.48 \\
\hline Total & 473 & 100 \\
\hline
\end{tabular}

Dengan pertumbuhan kosmetik asing yang positif dan signifikan, perlu diketahui, apa saja yang menyebabkan kosmetik asing mampu lebih berkembang dibandingkan dengan kosmetik lokal melalui pendekatan perspektif konsumen terhadap niat beli. Pada penelitian sebelumnya membahas niat beli konsumen pada produk dengan merek global melalui persepsi konsumen dari berbagai sisi prestige dan kualitas [6][7]. Pada penelitian lain yang dilakukan oleh Xie meneliti perbandingan secara langsung produk lokal dan global terhadap behavioral intention melalui aspek brand identity expressiveness, brand quality, brand prestige dengan mediasi brand trust dan brand affect [8].

\section{TINJAUAN PUSTAKA}

Kosmetik

Kosmetik adalah bahan atau sediaan yang dimaksudkan untuk digunakan pada bagian luar tubuh manusia (epidermis, rambut, kuku, bibir dan bagian luar) atau gigi dan membran mukosa mulut terutama untuk membersihkan, mewangikan, mengubah penampilan dan atau memperbaiki bau badan atau melindungi atau memelihara tubuh pada kondisi baik [9]. Dalam industri kosmetik Indonesia terdapat merek asing dan merek lokal, merek asing diasosiasikan dengan merek global. 
Tabel 2

Deskriptif Perilaku Pembelian Responden

\begin{tabular}{|c|c|c|}
\hline Perilaku Pembelian & Frekuensi & $\begin{array}{c}\text { Persentase } \\
(\%)\end{array}$ \\
\hline \multicolumn{3}{|l|}{ Pembelian Kosmetik Terakhir } \\
\hline Kurang dari 2 minggu yang lalu & 161 & 34.03 \\
\hline $2-3$ minggu yang lalu & 102 & 21.56 \\
\hline Sebulan yang lalu & 116 & 24.52 \\
\hline Lebih dari sebulan yang lalu & 94 & 19.87 \\
\hline \multicolumn{3}{|l|}{ Tempat Pembelian Kosmetik } \\
\hline Outlet atau toko fisik & 317 & 67.00 \\
\hline Pameran atau acara kosmetik & 7 & 1.48 \\
\hline Website & 19 & 4.02 \\
\hline Social media & 30 & 6.34 \\
\hline Aplikasi Toko Online & 100 & 21.14 \\
\hline \multicolumn{3}{|l|}{ Metode Pembayaran Pembelian Kosmetik } \\
\hline Pembayaran tunai & 285 & 60.25 \\
\hline Kartu debit & 99 & 20.93 \\
\hline Kartu kredit & 9 & 1.90 \\
\hline Internet banking & 16 & 3.38 \\
\hline Mobile banking & 56 & 11.84 \\
\hline \multicolumn{3}{|l|}{ Financial Technology (contoh: } \\
\hline ShopeePay, Saldo Tokopedia, dll) & 8 & 1.69 \\
\hline \multicolumn{3}{|l|}{ Kondisi Pendorong Pembelian Kosmetik } \\
\hline Diskon & 125 & 26.43 \\
\hline Penggunaan sampai habis & 243 & 51.37 \\
\hline Paket atau bundling yang menarik & 81 & 17.12 \\
\hline Pemberian bonus & 4 & 0.85 \\
\hline \multicolumn{3}{|l|}{ Kebutuhan mendadak dalam } \\
\hline perjalanan & 20 & 4.23 \\
\hline \multicolumn{3}{|l|}{ Frekuensi Mengganti Produk Kosmetik } \\
\hline Ketika habis & 218 & 46.09 \\
\hline Jika tidak cocok & 184 & 38.90 \\
\hline Setelah 6 bulan & 20 & 4.23 \\
\hline $6-12$ bulan & 15 & 3.17 \\
\hline Lebih dari satu tahun & 2 & 0.42 \\
\hline Lainnya & 34 & 7.19 \\
\hline Total & 473 & 100 \\
\hline
\end{tabular}

Merek asing adalah sebuah simbol dimana konsumen memiliki keyakinan bahwa merek tersebut memiliki kualitas lebih serta memiliki strategi pemasaran yang sama, nama, citra, harga, serta positioning yang sama secara global [10]. Merek asing atau global cenderung mendapatkan persepsi positif terhadap kualitas merek, prestise merek, citra harga diri, dan niat pembelian [7]. Sedangkan merek lokal merupakan produk yang berasal dari dalam negeri sendiri, di produksi dan dipasarkan di dalam negeri sendiri berbagai macam produk dimiliki oleh Indonesia, dari pakaian hinggu peralatan rumah tangga [11]. Pada negara berkembang konotasi merek lokal dapat memberikan dampak negatif, karena rasa kurang percaya terhadap kemampuan negeri sendiri dibanding negara lain yang telah maju.

\section{METODOLOGI PENELITIAN}

\section{A. Jenis Data}

Data primer merupakan data karakteristik demografi responden yang diperoleh menggunakan metode survei kuesioner pada responden yang dianggap telah mewakili sampel dari populasi penelitian [5]. Data yang diambil adalah data kuesioner penelitian dalam demografi responden.

\section{B. Pengumpulan Data}

Penelitian dilakukan dengan menggunakan metode survei melalui kuesioner yang disebar secara online [11]. Populasi dalam penelitian ini adalah seluruh wanita pengguna kosmetik aktif di Surabaya. Peneliti mengambil sampel dari populasi tersebut menggunakan teknik pengambilan sampel non-probability sampling [11]. Metode
Tabel 2

Deskriptif Perilaku Pembelian Responden (Lanjutan)

\begin{tabular}{lrr}
\hline \multicolumn{1}{c}{ Perilaku Pembelian } & Frekuensi & Persentase (\%) \\
\hline Pengaruh dalam Pembelian Kosmetik & & \\
Beauty vlogger & 171 & 36.15 \\
Diri sendiri & 168 & 35.52 \\
Iklan (TV, youtube, website, & 20 & 4.23 \\
dsb) & 79 & 16.7 \\
Teman & 24 & 5.07 \\
Keluarga & 3 & 0.63 \\
Review & 8 & 1.69 \\
Semua & & \\
\hline Pertimbangan Pembelian Kosmetik & 9 & 1.9 \\
Goodie Bag & 20 & 4.23 \\
Pelayanan yang ramah & 219 & 46.3 \\
Variasi beragam & 80 & 16.91 \\
Ketersediaan Stok & 145 & 30.66 \\
Lainnya & & \\
Frekuensi Rekomendasi Kosmetik & 29 & 6.13 \\
Selalu & 147 & 31.08 \\
Sering & 147 & 31.08 \\
Kadang-kadang & 137 & 28.96 \\
Sesekali & 13 \\
Tidak pernah & & 2.75 \\
Media Rekomendasi Kosmetik & 400 & 84.57 \\
Obrolan ringan & 32 & 6.77 \\
Review & 12 & 2.54 \\
Media sosial & 13 & 2.75 \\
Diskusi & 3 \\
Semua & 473 & 0.63 \\
Total & & 100 \\
\hline
\end{tabular}

pengambilan sampel yang digunakan adalah convenience sampling. Terdapat 473 kuesioner yang diperoleh setelah penyebarakan kuesioner dari bulan Oktober 2017 hingga November 2017. Analisis yang digunakan dalam penelitian ini merupakan analisis deskriptif terhadap demografi responden [11].

\section{IV.ANALISIS DAN PEMBAHASAN}

\section{A. $\quad$ Analisis Deskriptif}

Analisis deskriptif demografi dan usage dilakukan dalam penelitian ini untuk mengetahui karakteristik demografi responden dan penggunaan mengenai produk kosmetik yang beredar di Indonesia khususnya Surabaya. Berikut adalah hasil analisis demografi pengguna kosmetik pada Tabel 1.

Mayoritas responden dalam penelitian ini adalah wanita dengan mayoritas kelompok usia 21-25 tahun. Pendidikan terakhir didominasi oleh SMA/Sederajat sebanyak 63.41 persen. Pekerjaan terbanyak merupakan pelajar/mahasiswa dengan persentase sebesar 85.61 persen. Serta pemasukan respon sebanyak 72.29 persen berada pada kisaran dibawah Rp 2.000.000.

Waktu pembelian terakhir kosmetik terbanyak berada pada kurang dari dua minggu yang lalu dengan nilai 34.03 persen. Mayoritas tempat atau media pembelian kosmetik merupakan outlet atau toko fisik dengan angkia 67 persen. Pembayaran pembelian kosmetik didominasi dengan pembayaran tunai sebanyak 60.25. Kondisi pendorong pembelian kosmetik 51.37 persen ketika kosmetik habis.

Pengaruh dalam pembelian kosmetik dengan angka terbesar 36,15 persen dipengaruhi oleh beauty vlogger. Dalam pertimbangan pembelian kosmetik, mayoritas disebabkan variasi yang beragam sebesar 46,30 persen. Sebesar 31.08 persen sering dan 31.08 persen kadangkadang melakukan rekomendasi yang mayoritas dilakukan melalui obrolan ringan $(84,57 \%)$. 
Tabel 3

Deskriptif Usage Responden

\begin{tabular}{lrr}
\multicolumn{1}{c}{ USAGE } & FREKUENSI & $\begin{array}{c}\text { PERSENTASE } \\
(\%)\end{array}$ \\
\hline Usia Penggunaan Kosmetik Pertama Kali & 17 & 3.59 \\
10 - 14 Tahun & 262 & 55.38 \\
15 - 18 Tahun & 188 & 39.74 \\
19 - 22 Tahun & 6 & 1.27 \\
$>$ 22 Tahun & 247 & \\
\hline Frekuensi Penggunaan Kosmetik Pada Kehidupan Sehari-Hari & 52.21 \\
Selalu & 156 & 32.97 \\
Terkadang & 64 & 13.53 \\
Hanya Pada Acara Tertentu & 6 & 1.27 \\
Lainnya & & \\
\hline Pengeluaran Kosmetik tiap Bulan & 268 & 56.65 \\
- Rp 200.000 & 150 & 31.71 \\
Rp 200.000 - Rp 400.000 & 33 & 6.98 \\
Rp 400.000 - Rp 600.000 & 22 & 4.65 \\
$\geq$ Rp 600.000 & & \\
Kecenderungan Penggunaan Merek Kosmetik & 230 & 48.62 \\
Merek Asing & 109 & 23.04 \\
Merek Lokal & 134 & 28.32 \\
Merek Lokal Berskala Global & 473 & 100 \\
\hline Total & & \\
\hline \hline
\end{tabular}

Usia penggunaan kosmetik pertama kali mayoritas berada pada kisaran umur 15 hingga 18 tahun 55.38 persen. Pada pengeluaran kosmetik, responden penelitian mayoritas memilih pada angka dibawah Rp 200.000 yaitu sebesar 56.65 persen. Frekuensi penggunaan kosmetik pada kehidupan sehari-hari pada penelitian ini sebagian besar berada pada selalu dengan angka 52.21 persen. Pada kecenderungan merek kosmetik yang digunakan, sebesar 48.62 persen berada pada merek asing

Pada jenis kosmetik wajah dan bibir termasuk memiliki persentase penggunaan terbesar pada kategori selalu sebesar 37.41 persen dan 55.8 persen. Sedangkan kosmetik mata mayoritas penggunaan terbesar pada kadangkadang dan sesekali dengan persentase 32.13 persen dan 30,23 persen.

\section{KESIMPULAN}

\section{A. Kesimpulan}

Analisis deksriptif profil dalam penelitian ini menunjukkan bahwa pengguna kosmetik asing didominasi dengan wanita usia muda pada kisaran usia 21 hingga 25 tahun, karena perkembangan teknologi dan tren kosmetik pda kalangan usia muda. Karema mayoritas pekerjaan responden merupakan pelajar/mahasiswa dengan mayoritas pendidikan terakhir SMA/Sederajat sehingga memiliki pendapatan yang rendah dikarenakan pelajar atau mahasiswa belum memiliki penghasilan sendiri. Secara umum, pengeluaran untuk kosmetik menjadi tidak besar.

Analisis deskriptif perilaku pembelian memiliki hasil berupa pengguna kosmetik aktif didominasi pembelian kurang dari 2 minggu yang lalu melalui toko atau outlet fisik dengan metode pembayaran tunai. Faktor pendorong dan frekuensi penggantian kosmetik mayoritas dipengaruhi oleh habisnya produk kosmetik yang digunakan. Dalam pembelian kosmetik pengaruh paling besar merupakan pengaruh dari beauty vlogger atau inlfuencer dengan pertimbangan variasi yang ditawarkan. Selain mengikuti beauty vlogger, responden diketahui juga sering melalukan rekomendasi melalui obrolan ringan mengenai kosmetik yang digunakan.
Tabel 3

Deskriptif Usage Responden (Lanjutan)

\begin{tabular}{lrr}
\hline \hline \multicolumn{1}{c}{ Usage } & Frekuensi & Persentase $(\%)$ \\
\hline Penggunaan Kosmetik Berdasarkan Jenisnya & \\
Kosmetik Wajah & & \\
Tidak Pernah & 9 & 1.90 \\
Sesekali & 69 & 14.58 \\
Kadang-Kadang & 92 & 19.45 \\
Sering & 126 & 26.63 \\
Selalu & 177 & 37.41 \\
\hline Kosmetik Bibir & & \\
Tidak Pernah & 0 & 0.00 \\
Sesekali & 20 & 4.23 \\
Kadang-Kadang & 70 & 14.80 \\
Sering & 119 & 25.15 \\
Selalu & 264 & 55.80 \\
\hline Kosmetik Mata & & \\
Tidak Pernah & 62 & 13.11 \\
Sesekali & 143 & 30.23 \\
Kadang-Kadang & 152 & 32.13 \\
Sering & 71 & 15.01 \\
Selalu & 45 & 9.51 \\
\hline \hline
\end{tabular}

Analisis deskriptif usage menunjukkan bahwa kebanyakan usia penggunaan kosmetik pertaman kali berada pada rentang usia 15 hingga 18 tahun yang merupakan tahapan remaja. Pada frekuensi penggunaan juga selalu pada keseharian responden. Pengeluaran kosmetik pada tiap bulannya, sebagian besar responden berada pada angka sama atau lebih kecil dari Rp 200.000 yang merupakan 10 persen dari mayoritas pemasukan. Responden diketahui memiliki kecenderungan atau kesenangan pada kosmetik merek asing, dengan penggunaan intens pada jenis kosmetik bibir.

\section{B. Saran}

Saran untuk penelitian selanjutnya dapat meneliti mengenai perbandingan kosmetik asing dan lokal pada pasar kosmetik Indonesia. Penelitian selanjutnya juga dapat meneliti strategi perusahaan yang tepat bagi satu perusahaan kosmetik lokal secara spesifik, mengingat masing-masing perusahaan memiliki keunggulan dan karakteristik yang berbeda.

\section{DAFTAR PUSTAKA}

[1] IBIS World, "Global Cosmetic Market," 2016. [Online]. Available: www.raconteur.net/infographics.

[2] Allied Market Research, "Report Overview Global Opportunity Analysis and Industry Forecast, 2014 - 2022," 2016.

[3] MARS Indonesia, "Studi Pemasaran Kosmetik 2017," 2017.

[4] Kementrian Perindustrian, "Susahnya Kosmetik Lokal Berjaya di Nusantara: Bahan Baku Impor 70 Persen," 2017. [Online] Available: http://www.kemenperin.go.id/artikel/6018/SusahnyaKosmetik-Lokal-Berjaya-di-Nusantara:-Bahan-Baku-Impor-70Persen.

[5] Shopee, "Kategori Kosmetik," Shopee.co.id, 2017. [Online]. Available: https://shopee.co.id/Kosmetik-cat.156.

[6] A. Akram, D. Merunka, and M. S. Akram, "Perceived brand globalness in emerging markets and the modeling role of consumer ethnocentrism," Int. J. Emerg. Mark., pp. 291-303, 2011 .

[7] Winit and et al, "Global vs local brands: how home country bias and price differences," Int. Mark. Rev., vol. 31, no. 2, pp. 102$128,2014$.

[8] Y. Xie, R. Batra, and S. Peng, "An Extended Model Formation Between Global and Local Brands: The Roles of Identity Expressiveness, Trust, and Affect," Jounal Intenational Mark. $A M A$, vol. 23, no. 1, pp. 50-71, 2015.

[9] Z. Ismail, "Factors Affecting Consumer Preference of International Brands over Local Brands," in 2nd International Conference on Social Science and Humanity IPEDR, 2012.

[10] W. Keegan, Global Marketing Management, 7th ed. New Jersey: Prentice Hal, Inc, 2002. 
[11] Sugiyono, Statistika untuk Penelitian. Bandung: Alfabeta, 2005. 